\title{
А.П. Красовский
}

\section{О МЕТОДИКЕ ИДЕНТИФИКАЦИИ СЕЛЬСКИХ ПОСЕЛЕНИЙ С ИСПОЛЬЗОВАНИЕМ ИМЕЮЩИХСЯ О НИХ СВЕДЕНИЙ В ДОКУМЕНТАХ И НА КАРТОГРАФИЧЕСКИХ МАТЕРИАЛАХ ХУІ-ХІХ ВВ. (НА ПРИМЕРЕ СЁЛ РУЗСКОГО УЕЗДА МОСКОВСКОЙ ГУБЕРНИИ)}

\begin{abstract}
АННОТАЦИЯ
Представляемая в настоящей статье работа посвящена разрешению проблемы поиска сведений о поселениях в материалах XVI-XIX вв. при выполнении исторических, генеалогических, краеведческих и подобных им исследований, возникающей вследствие неустойчивости во времени их названий.

Установлено, что первоначально эта проблема (проблема идентификации) решалась путём указания в документах дополнительно к названиям поселений разнообразных признаков, а в последующем - дополнительно к этому, и составлением чертежей и планов, изображавших взаимное расположение поселений и окружавших их объектов. Однако систематизации указываемых признаков и методики их использования, пригодной для составления алгоритмов функционирования современных геоинформационных систем, до настоящего времени не разработано.

В представляемой в настоящей статье работе на основе сведений о сёлах Рузского уезда Московской губернии, содержащихся как непосредственно в исторических документах XVI-XIX вв., так и в обобщающей их литературе (т.е. на основе сведений писцовых, переписных, метрических, межевых, дозорных, окладных, приходных, доимочных и оброчных книг, а также исповедных ведомостей), и на картографических материалах XVII-XIX вв. (чертежах, планах, картах и одной схеме) сформулированы критерии идентификации сёл и предложена методика её выполнения.

Выполнена систематизация фактологического материала и его представление в табличном виде, пригодном как для целей представляемого исследования, так и для использования другими специалистами, работающими в смежных областях науки и практической деятельности. Выполненные апробация предложенной методики и оценка её эффективности показали возможность применения результатов представляемой работы для практического использования.
\end{abstract}

КЛЮЧЕВЫЕ СЛОВА: Рузский уезд Московской губернии, писцовые, переписные, метрические и межевые книги, исповедные ведомости, чертежи, планы, карты и схемы территории Русского государства XVII-XIX вв.

\footnotetext{
${ }^{1}$ Государственный университет по землеустройству, Факультет землеустройства, ул. Казакова, д. 15, 105064, Москва, Россия; e-mail: anton.krass@gmail.com
} 


\title{
Anton P. Krassowski ${ }^{1}$
}

\section{ABOUT METHODOLOGY OF IDENTIFICATION OF RURAL SETTLEMENTS WITH USING THE AVAILABLE INFORMATION ABOUT THEM IN DOCUMENTS AND CARTOGRAPHIC MATERIALS OF THE $16^{\text {th }}-19^{\text {th }}$ CENTURIES (ON THE EXAMPLES RURAL OF RUZSKY DISTRICT MOSCOW PROVINCE)}

\begin{abstract}
The research presented in this article is devoted to solving the problem of searching for information about rural in the materials of the $16^{\text {th }}-19^{\text {th }}$ centuries when performing historical, genealogical, local history and similar studies, which arise as a result of the instability in time of their names and changes in the places where information about them is stored.

The study found that initially this problem (the problem of identification) was solved by specifying various features for rural in documents in addition to their names, and later - in addition to this, by drawing up drawings and plans depicting the mutual location of rural and surrounding terrain objects, however, the systematization of these features and methods of their use, suitable for use in the preparation of algorithms for the functioning of modern geoinformation systems has not been developed so far.

We present in this article the work is done using information about the rural of Ruzsky district, Moscow province contained in the historical documents of $16^{\text {th }}-19^{\text {th }}$ centuries and a synthesis of their literature (Cadastre, Census, Metric, Boundary, Sentinel, Accountant, Income, Domashnih and Quitrent books, as well as in the Confessional statements), and on cartographic materials of the $17^{\text {th }}-19^{\text {th }}$ centuries (drawings, plans, maps and one diagram), on the basis of which criteria identification of rural and the methodology of its implementation.

In the course of the work, the systematization of the factual material and its presentation in tabular form, suitable both for the purposes of the presented research, and for use by other specialists working in related fields of science and practice. The approbation of the proposed method, the evaluation of its effectiveness and the results obtained in the course of this work showed the possibility of applying the results of the presented work for practical use.
\end{abstract}

KEYWORDS: Ruzsky district of Moscow province, Scribal, Census, Metric and Boundary books, Confessional sheets, Drawings, Plans, Maps and Diagrams of the territory of the Russian State of the $17^{\text {th }}-19^{\text {th }}$ centuries

\section{ВВЕДЕНИЕ}

Проблема отыскания сведений о сельских поселениях Русского государства XVI-XIX вв. в исторических материалах хорошо известна историкам, генеалогам, краеведам, а также специалистам, работающим в иных областях науки и практической деятельности. В большинстве случаев она вызвана тем, что в составленных в различные эпохи материалах одно и то же поселение может фигурировать под различными названиями.

На протяжении XVI-XIX вв. в российской практике данная проблема вначале решалась путём указания для поселений дополнительно к их названиям каких-либо признаков, а позднее - дополнительно к этому, путём составления изображавших взаимное расположение поселений и иных объектов местности чертежей, планов и схем.

Однако, несмотря на многовековую практику применения различных способов разрешения проблемы отыскания сведений о поселениях при изменении их названий,

\footnotetext{
${ }^{1}$ State University of Land Use Planning, Faculty of Land Use Planning, Kazakov str., 15, 105064, Moscow, Russia; e-mail: anton.krass@gmail.com
} 
формализации применяемых для этого способов выполнено не было. В настоящее же время разработка такой методики и создание на её основе соответствующего алгоритма могут содействовать повышению эффективности функционирования геоинформационных систем, аккумулирующих и предоставляющих информацию о поселениях.

Процесс отыскания поселения с использованием совокупности сведений о нём среди прочих по своей сути является процессом идентификации. В настоящей статье под идентификацией будет пониматься процесс выделения объекта (поселения) из совокупности однородных с ним объектов (поселений) по совпадению характерных для него критериев (под которыми будут пониматься дополнительные признаки поселений). Применительно к теме настоящей работы процесс идентификации - это процесс установления соответствия приводимых в материалах различных эпох сведений одному и тому же поселению, упоминаемому в материалах под различными названиями.

В связи с вышеизложенным, перед представляемым в настоящей статье исследованием были поставлены следующие цели: сформулировать критерии, с использованием которых станет возможным утверждать, что приводимые в материалах различных эпох сведения относятся к одному и тому же поселению, название которого с течением времени претерпело изменения; разработать соответствующую методику, а также провести её апробацию и оценить эффективность.

Идентификация поселений разнообразных типов (сёл, селец, деревень, слобод и прочих) является задачей высокой сложности ввиду несхожести свойственных для них характеристик и отсутствия единой системы их представления в материалах, составленных в различные эпохи. Поэтому в настоящем исследовании было решено ограничиться рассмотрением идентификации сёл, т.к. сведения именно о сёлах являются наиболее систематизированными в документах, а их получение возможно из большого количества материалов как светских, так и церковных.

Вследствие необходимости привлечения и анализа для выполнения указанной работы большого объёма материала, её было решено выполнить на основе материалов о сёлах Рузского уезда Московской губернии XVI-XIX вв., которыми его автор располагал в результате своей практической деятельности. Не исключено, что систематизированные сведения о некоторых из идентифицированных в процессе выполнения представляемого исследования поселений и информация о местах их хранения будут полезны другим специалистам и обеспечат им возможность использования их первоисточников, а предложенная методика идентификации будет использована, в том числе и разработчиками геоинформационных систем, осуществляющими сопоставление источников информации, относящихся к различным эпохам.

Для достижения поставленных целей в представляемой работе потребовалось решить следующие задачи:

- выявить максимально возможное количество находящихся в свободном доступе пригодных для выполнения работы картографических материалов (чертежей, межевых планов, карт и схем), отображающих территорию Рузского уезда;

- проанализировать документарные источники сведений о поселениях XVI-XIX вв. и сформировать оптимальную выборку из них, пригодную для сопоставления предоставляемых ими сведений со сведениями картографических материалов;

- установить и систематизировать применяемые в указанных выше материалах и обобщающей их литературе дополнительные признаки поселений и сформировать оптимальную последовательность их использования.

Новизной представляемого в настоящей работе исследования являются выделение, систематизация и организация идентификационных критериев поселений в упорядоченную структуру, а также разработанная в её результате методика идентификации. 


\section{МАТЕРИАЛЫ И МЕТОДЫ ИССЛЕДОВАНИЙ}

Приступая к изложению существа представляемого исследования, следует дать определение типа поселения «село», которое будет достаточным для достижения поставленных целей. В качестве такового было решено принять одно из определений, данных в Энциклопедическом словаре Брокгауза и Ефрона ${ }^{1}$, которое под селом понимает «... крестьянское селение, в котором есть церковь». Это позволяет в настоящей работе считать селом населённый пункт с расположенным на его территории храмом. Следуя этому определению, можно заключить, что приобретение поселением типа «село» связано либо с основанием на его территории храма, либо с вхождением в его территорию землевладения с расположенным на нём храмом, что неразрывно связывает истории сёл с историями расположенных на их территориях храмов. Поэтому при выполнении представляемого исследования столь пристальное внимание было уделено изучению материалов, содержащих сведения об историях располагавшихся на территории уезда храмов, причём из всего множества обнаруженных материалов были избраны лишь те, которые оказались необходимыми для достижения поставленных целей.

В анализируемую совокупность были включены как все сёла, перечисленные в Реестре метрических книг Рузского уезда за 1912 г., находящегося на хранении в Центральном государственном архиве города Москвы² тории уезда на Схеме церковных приходов 1877 г. (см. ниже). Общее количество сёл, сведения о которых были проанализированы, составило 50.

Вначале назовём использованные в работе картографические материалы, отображающие территорию Рузского уезда.

Наиболее древними из таковых являются чертежи, представленные специализированной веб-ГИС «Чертежи Русского Государства XVII-XVIII вв.», интегрированной с сайтом Российского государственного архива древних актов ${ }^{3}$, которые датируются второй половиной XVII века [Фролов и др., 2017]. Так как таких чертежей оказалось всего 16, а изображено на них в общей сложности оказалось лишь 14 объектов, пригодных для выполнения исследования (сёл и поселений иных типов, из которых сёла были образованы впоследствии), то следует отметить, что соответствующая эпоха в исследовании представлена весьма неполно.

Картой, с которой были «сняты» типы и названия поселений, соответствующие XVIII в., явилась Географическая карта 1774 г. ${ }^{4}$, составленная на основе межевых планов ${ }^{5,6}$, изготовленных по итогам Генерального межевания.

\footnotetext{
1 Энциклопедический словарь Брокгауза и Ефрона онлайн. Электронный ресурс: http://www.vehi.net/brokgauz/ (дата обращения 12.02.2019)

Brockhaus and Efron encyclopedic dictionary online. Web resource: http://www.vehi.net/brokgauz/ (accessed 12.02.2019) (in Russian)

2 ЦГАМ, Ф. 203, Оп. 780, С. 159-162

${ }^{3}$ Веб-ГИС «Чертежи Русского государства XVI-XVII вв.». Электронный ресурс: http://rgada.info/geos2 (дата обращения 27.09.2019)

Web-GIS "Drawings of the Russian state XVI-XVII centuries". Web resource: http://rgada.info/geos2 (accessed 27.09.2019) (in Russian)

4 Географическая карта Московской провинции, сочинённая с Генеральных Уездных межевых планов попечением Межевой Канцелярии членом Коллежского Советника Зенбулатова и Инженер Майором и над Чертёжною Директором Горихвостовым 1774 г. РГБ, Электронный ресурс от 11 декабря 2017 г.

Geographical map of the Moscow province, composed from the General district boundary plans by the care of the Boundary Office of a member of the Collegiate Councilor Zenbulatov and Engineer Major and above the Drawing Director Gorikhvostov 1774. RSL, Web resource (accessed 12.09.2018) (in Russian)

5 План генерального межевания одновёрстного масштаба 1792 г.

Plan of the General survey of the single-layer scale of 1792 (in Russian)

${ }^{6}$ План генерального межевания двухвёрстного масштаба 1797 г.

Plan of the General survey of the double-layer scale of 1797 (in Russian)
} 
Век XIX представлен Топографической картой Московской губернии 1860 г. ${ }^{1}$. Её особенность состоит в том, что она оказалась изготовленной столь удачно, что использовалась в качестве основы для составления большинства специальных карт вплоть до двадцатых годов XX в., вследствие чего их рассмотрение в интересах настоящего исследования потеряло смысл.

И завершает перечень использованных образцов картографических материалов Схема церковных приходов и волостей Можайского и Рузского уездов 1877 г. ${ }^{2}$, составленная по поручению Московской губернской земской санитарной комиссии С. Матвеевым. Указанные на этой схеме названия некоторых сёл столь значительно отличаются от указанных на других картографических материалах, что обойти её вниманием не представляется возможным, несмотря на её узкоспециальное назначение.

Теперь перечислим документы различных эпох, из которых выбирались сведения о сёлах (названия, сведения о расположении, владельцах и прочие).

Наиболее древними документами, XVI в., являются приправочные списки писцовых книг Рузского [Кистерёв и др., 1997] и Звенигородского [Кондрашина и др., 1992] уездов.

Промежуток времени примерно с начала XVII в. и до второй половины XVIII в. представлен сведениями Исторических материалов для составления церковных летописей Московской епархии [Холмогоровы, 1881, вып. 1, 2, 3; Холмогоровы, 1901, вып. 10; Холмогоpoвbl, 1913, вып. 13], в которых, согласно представленным в них пояснениям, обобщены материалы, находившиеся на хранении в конце XIX - нач. XX вв. в московском архиве Министерства Юстиции. В их число входили составляемые для территории Рузского и смежных с ним уездов следующие документы:

- писцовые, переписные и межевые книги;

- д дозорные книги Патриаршего Казённого приказа;.

- дозорные книги пустынных церковных земель;

- окладные приходные книги Патриаршего Казённого приказа жилых церквей;

- окладные приходные книги Патриаршего Казённого приказа оброчных земель;

- приходные книги жилых церквей;

- приходные книги Патриаршего Казённого приказа оброчных земель;

- доимочные книги оброчных церковных земель;

- оброчные приходные книги Патриаршего Казённого приказа.

Несмотря на то что летописи предназначались их авторами для составления исторических справок о храмах, располагавшихся на территориях сёл, а не самих сёл, приводимые в них цитаты из указанных выше документов значимы и для представляемого исследования.

Сведения, относящиеся к промежутку времени со второй половины XVIII в. и по начало XX в. (включительно), были получены из документов Духовной консистории, а именно: из метрических книг и исповедных ведомостей церквей Рузского и Звенигородского уездов, находящихся на хранении в Центральном государственном архиве города Москвы.

Сведения о владельцах некоторых из сёл были получены из Книги дворянских родов Российской Империи [Бобринский, 1890, т. 1], представляющей как необходимый перечень персон, так и даты пожалования им на территории Рузского уезда имений.

\footnotetext{
1 Топографическая карта Московской губернии 1860 г.

Topographic map of Moscow province 1860 (in Russian)

${ }^{2}$ Схема церковных приходов и волостей Можайского и Рузского уездов 1877 г., составленная по поручению Московской губернской земской санитарной комиссии С. Матвеевым

The Scheme of Church parishes and volosts of Mozhaisky and Ruzsky district of 1877, made on behalf of the Moscow provincial Zemsky sanitary Commission by S. Matveev (in Russian)
} 
В ряде наиболее трудных случаев выполнения идентификации приходилось обращаться к Межевым описаниям и схемам, составленным для территории Рузского уезда профессором В.С.Кусовым [Кусов, 2004; Кусов, 2007], а также информации, предоставляемой электронным периодическим изданием «Храмы России» ${ }^{1}$.

Фактологический материал, использованный при выполнении настоящего исследования, представлен в табл. 1.

В таблице на первое место помещён столбец, содержащий названия сёл, приводимые в реестре Метрических книг 1912 г., в силу того что именно эти названия используются специалистами наиболее часто. Вследствие того, что на протяжении XVI-XIX вв. некоторые из рассматриваемых поселений в результате тех или иных событий утрачивала тип «село», в то время как другие этот тип приобретали, в таблице можно встретить и поселения таких типов, как: «сельцо», «деревня», «слобода» и «погост» ${ }^{2}$ и даже землевладения, например, «пустошь» и «церковная земля».

Поскольку для выполнения исследования удалось обнаружить картографические материалы, составляемые, за единственным исключением, примерно один раз в сто лет, т.е. в 1651-1700, 1774, 1860 и 1877 гг., то, по большей части, оказалось достаточным сгруппировать сведения о поселениях в столбцы таблицы, соответствующие столетиям.

Указываемые названия поселений и сопровождающие их в необходимых случаях комментарии приведены в таблице в том виде, в котором они присутствуют в документах и на картографических материалах соответствующих эпох. Поэтому в случаях значительных отличий их написаний, как и сопровождающих их оборотов речи от современных норм, они указаны в кавычках.

Для идентификации сёл в проблематичных случаях, а также для облегчения отыскания их на картографических материалах и сведений о них в документах, в соответствующих ячейках таблицы указаны наиболее существенные их идентификационные критерии, которые использовались в различные эпохи, в том числе, например, для различения двух расположенных рядом поселений с одинаковыми названиями [Красовский, Тетерюков, 2019; Красовский, 2020].

В основу предлагаемой методики идентификации положено использование сведений, указываемых в документах дополнительно к названиям сёл, и информации, имеющейся на картографических материалах. Эти сведения предлагается называть идентификационными критериями. Используемые в качестве идентификационных критериев сведения о сёлах в процессе выполнения настоящего исследования были выделены из материалов Рузского уезда различных эпох, систематизированы и представлены в табл. 2 в порядке убывания частоты использования (колонка 2).

Соответствующие различным эпохам сведения о селе предлагается организовывать в пары для выполнения сравнения на предмет отыскания совпадений. Совпадение сопоставляемых критериев в паре свидетельствует о том, что в материалах различных эпох под различными названиями может упоминаться одно и тоже же село, а совпадение нескольких таких пар критериев - установлению этого обстоятельства. При несовпадении критериев

\footnotetext{
1 Электронное периодическое издание «Храмы России». Электронный ресурc: http://www.temples.ru/ (дата обращения 29.11.2017)

Electronic periodical publication “Temples of Russia”. Web resource: http://www.temples.ru/ (accessed 29.11.2017) (in Russian)

${ }^{2}$ Наиболее подходящим для целей выполнения настоящего исследования определением термина «погост» является: «... крупное селение с церковью и кладбищем...». Большой энциклопедический словарь. Электронный pecypc: http://niv.ru/doc/dictionary/big-encyclopedic/fc/slovar-207-28.htm\#zag-50443 (дата обращения 12.02.2019)

The most appropriate definition of the term "churchyard" for the purposes of this study is: “... a large village with a Church and a cemetery...”. Large encyclopedic dictionary. Web resource: http://niv.ru/doc/dictionary/big-encyclopedic/fc/slovar-207-28.htm\#zag-50443 (accessed 12.02.2019) (in Russian)
} 
в паре требуется перейти сравнению составляющих следующую пару критериев. Сравнение критериев в парах рекомендуется выполнять, начиная с верхней строки и последовательно продвигаясь по срокам таблицы сверху вниз, т.к. такому порядку соответствует уменьшение количества успешных использований критериев, о чём будет сказано ниже.

В случае безуспешности попытки идентификации собранные в процессе её осуществления сведения и знания выполняющим её специалистом способов образования названий сёл (поселений) могут быть использованы для выдвижения предположений о том, какими могло бы быть название не идентифицированного в документах села, которое, будучи принятым за возможное, может обеспечить получение желаемого результата после повторного выполнения для него процедуры идентификации.

\section{РЕЗУЛЬТАТЫ ИССЛЕДОВАНИЙ И ИХ ОБСУЖДЕНИЕ}

Апробация изложенной выше методики идентификации была проведена на основе упоминаемых в материалах различных эпох сведений об указанной выше совокупности сёл. В результате была показана способность методики обеспечить получение результата как в случаях изменения названия села (в том числе и в случае изменения типа поселения), так и изменения его принадлежности к административно-территориальным (церковно-территориальным) единицам (что позволяет обнаружить места хранения источников сведений, т.к. они зависят от принадлежности села к той или иной территориальной единице).

Также использование описанной выше методики идентификации в отношении, как кажется на первый взгляд, надёжно идентифицированных в различных материалах поселений с одинаковыми названиями, позволяет исключить ошибки идентификации, что особенно актуально для XVI-XVII вв., т.к. чертежи с указанием местоположений поселений в эту эпоху составлялись в исключительно редких случаях.

Приступая к рассмотрению результатов апробации и применения предложенной методики идентификации, следует отметить, что названия 18 из 50 составляющих анализируемую совокупность сёл (см. табл. 1) на протяжении всего рассматриваемого промежутка времени оставались практически неизменными, в результате чего использование сведений о них в целях настоящего исследования оказалось невозможным. Группа из оставшихся 32 сёл была разделена на три следующие подгруппы:

- сёла с изменявшимися в течение рассматриваемого промежутка времени названиями (21 село) с использованием сведений, о которых удалось выполнить апробирование методики идентификации;

- сёла, сведения о которых удалось обнаружить в документальных источниках в результате применения апробированной на предыдущем этапе методики (6 сёл);

- сёла, сведения о которых не могли быть использованы при проведении настоящего исследования ввиду относительно короткой истории их существования (5 сёл).

В табл. 2 представлены сведения о количестве успешных использований каждого из идентификационных критериев как на этапе апробации предложенной методики (столбец 3), так и на этапе её использования (столбец 4). Следует заметить, что превышение суммарного количества сёл, идентифицированных с использованием указанных в таблице критериев, свидетельствует о том, что некоторые из сёл были успешно идентифицированы с одновременным использованием двух и более критериев.

Из представленного в столбце 3 материала можно видеть, что на этапе апробации методики наиболее часто получение результата обеспечивало известное освящение расположенного на территории села храма; вторым по количеству успешных случаев идентификации являлся признак отнесения села (поселения) к стану; третьим - сведения о владельцах села и т.д. Однако следует заметить, что практика выполнения подобных 
Табл. 1. Сведения о сёлах и погостах Рузского уезда

Table 1. Information about rural and churchyards of Ruzsky district

\begin{tabular}{|c|c|c|c|c|c|c|c|c|c|}
\hline \multirow{2}{*}{ №№ } & \multirow{2}{*}{$\begin{array}{c}\text { Названия сёл } \\
\text { (погостов), } \\
\text { используемые } \\
\text { в документах } \\
\text { XIX в. }\end{array}$} & \multirow{2}{*}{$\begin{array}{c}\text { Освящения } \\
\text { храмов, } \\
\text { расположен- } \\
\text { ных на } \\
\text { терри- } \\
\text { ториях сёл } \\
\text { (погостов) в } \\
\text { XVI-ХIX вв. }\end{array}$} & \multicolumn{3}{|c|}{$\begin{array}{c}\text { Типы и названия поселений (землевладений) и } \\
\text { дополнительные сведения о них (при необходи- } \\
\text { мости), содержащиеся в документах XVI-XVIII } \\
\text { вв. }\end{array}$} & \multicolumn{4}{|c|}{$\begin{array}{c}\text { Типы и названия поселений (землевладений), } \\
\text { отражённые на картографических материалах XVII-XIX вв. }\end{array}$} \\
\hline & & & $\begin{array}{l}\text { На } \\
\text { протяжении } \\
\text { XVI в. }\end{array}$ & $\begin{array}{l}\text { На } \\
\text { протяжении } \\
\text { XVII в. }\end{array}$ & $\begin{array}{l}\text { На протяжении } \\
\text { XVIII в. }\end{array}$ & $\begin{array}{l}\text { Чертежи } \\
\text { XVII в. }{ }^{1}\end{array}$ & $\begin{array}{l}\text { Географическ } \\
\text { ая карта } \\
1774 \text { г. }\end{array}$ & $\begin{array}{l}\text { Топографи- } \\
\text { ческая карта } \\
1860 \text { г. }^{3}\end{array}$ & $\begin{array}{c}\text { Сема } \\
\text { церковных } \\
\text { приходов } \\
1877 \text { г. } \\
\end{array}$ \\
\hline \multicolumn{10}{|c|}{ Сёла, названия которых не изменялись в течение рассматриваемого периода времени } \\
\hline 1. & $\begin{array}{c}\text { Село } \\
\text { Абрамово } \\
\end{array}$ & $\begin{array}{l}\text { Происхож- } \\
\text { денческий }\end{array}$ & \begin{tabular}{c|} 
Сельцо \\
Абрамово \\
\end{tabular} & \begin{tabular}{|c|} 
Сельцо \\
Абрамово \\
\end{tabular} & \begin{tabular}{c|} 
Сельцо, село \\
Абрамово \\
\end{tabular} & - & $\begin{array}{c}\text { Село } \\
\text { Абрамово } \\
\end{array}$ & $\begin{array}{c}\text { Село } \\
\text { Абрамово } \\
\end{array}$ & $\begin{array}{c}\text { Село } \\
\text { Абрамово } \\
\end{array}$ \\
\hline 2. & $\begin{array}{c}\text { Село } \\
\text { Алексино } \\
\end{array}$ & Покровский & $\begin{array}{c}\text { Село } \\
\text { Олексино } \\
\end{array}$ & $\begin{array}{c}\text { Село } \\
\text { Алексино } \\
\end{array}$ & $\begin{array}{c}\text { Село } \\
\text { Алексино } \\
\end{array}$ & - & $\begin{array}{c}\text { Село } \\
\text { Алексино } \\
\end{array}$ & $\begin{array}{c}\text { Село } \\
\text { Алексино } \\
\end{array}$ & $\begin{array}{c}\text { Село } \\
\text { Алексино } \\
\end{array}$ \\
\hline 3. & $\begin{array}{c}\text { Село } \\
\text { Ащерино }\end{array}$ & $\begin{array}{c}\text { Иоанно- } \\
\text { Предтеченский }\end{array}$ & $\begin{array}{c}\text { Село } \\
\text { Ощерино }\end{array}$ & $\begin{array}{l}\text { Село, пустошь, } \\
\text { село Ощерино }\end{array}$ & $\begin{array}{c}\text { Село } \\
\text { Ощерино } \\
\text { (Ащерино) }\end{array}$ & - & $\begin{array}{c}\text { Село } \\
\text { Ащерино }\end{array}$ & $\begin{array}{c}\text { Село } \\
\text { Ащерино }\end{array}$ & $\begin{array}{c}\text { Село } \\
\text { Ащерино }\end{array}$ \\
\hline 4. & $\begin{array}{c}\text { Село } \\
\text { Борзецово } \\
\end{array}$ & Успенский & $\begin{array}{c}\text { Сельцо } \\
\text { Борзецово } \\
\end{array}$ & $\begin{array}{c}\text { Село, сельцо, } \\
\text { село Борзецово }\end{array}$ & $\begin{array}{c}\text { Село } \\
\text { Борзецово } \\
\end{array}$ & - & $\begin{array}{c}\text { Село } \\
\text { Борзецово } \\
\end{array}$ & $\begin{array}{c}\text { Село } \\
\text { Борзецово } \\
\end{array}$ & $\begin{array}{c}\text { Село } \\
\text { Борзецово } \\
\end{array}$ \\
\hline 5. & $\begin{array}{l}\text { Село Васильев- } \\
\text { ское } \\
\text { (на реке } \\
\text { Москве) } \\
\end{array}$ & Воскресенский & $\begin{array}{c}\text { Село } \\
\text { Васильевское }\end{array}$ & $\begin{array}{c}\text { Село } \\
\text { Васильевское } \\
\text { (Городского } \\
\text { стана) } \\
\end{array}$ & $\begin{array}{c}\text { Село } \\
\text { Васильевское }\end{array}$ & - & $\begin{array}{c}\text { Село } \\
\text { Васильевское }\end{array}$ & $\begin{array}{c}\text { Село } \\
\text { Васильевское }\end{array}$ & $\begin{array}{c}\text { Село } \\
\text { Васильевское }\end{array}$ \\
\hline 6. & $\begin{array}{c}\text { Село } \\
\text { Воскресенское } \\
\end{array}$ & Воскресенский & $\begin{array}{c}\text { Село } \\
\text { Воскресенское } \\
\end{array}$ & $\begin{array}{l}\text { Село Воскресен- } \\
\text { ское на р. Пальне } \\
\end{array}$ & $\begin{array}{c}\text { Село } \\
\text { Воскресенское } \\
\end{array}$ & - & $\begin{array}{c}\text { Село } \\
\text { Воскресенское } \\
\end{array}$ & $\begin{array}{c}\text { Село } \\
\text { Воскресенки } \\
\end{array}$ & $\begin{array}{c}\text { Село } \\
\text { Воскресенское } \\
\end{array}$ \\
\hline 7. & $\begin{array}{c}\text { Село } \\
\text { Казаново } \\
\end{array}$ & $\begin{array}{c}\text { Рождества } \\
\text { Богородицы }\end{array}$ & $\begin{array}{c}\text { Село, сельцо } \\
\text { Казаново } \\
\end{array}$ & \begin{tabular}{|c|} 
Сельцо, село \\
Казаново \\
\end{tabular} & $\begin{array}{c}\text { Село } \\
\text { Казаново } \\
\end{array}$ & - & $\begin{array}{c}\text { Село } \\
\text { Казаново } \\
\end{array}$ & $\begin{array}{c}\text { Село } \\
\text { Казаново } \\
\end{array}$ & $\begin{array}{c}\text { Село } \\
\text { Казаново } \\
\end{array}$ \\
\hline
\end{tabular}

1 Чертежи, сведения с которых приведены в настоящем столбце, датируются примерно второй половиной XVII в. [Фролов и др., 2017]

2 Примерно в трети названий поселений Рузского уезда [Красовский, 2018] карта содержит искажения названий, в нескольких случаях - пропуски названий и одну замену одного названия другим, вызванные явно случайными ошибками. В следствие этого внесённые в таблицу названия поселений указаны после их сверки с Межевыми планами, на основе которых карта была составлена

${ }^{3}$ Вследствие крупного масштаба карты места расположений поселений и храмов на ней указаны раздельно, к тому же на карте не указаны типы поселений, поэтому о типах каждого из поселений приходится судить только исходя из близости расположния к нему того или иного храма 


\begin{tabular}{|c|c|c|c|c|c|c|c|c|c|}
\hline 8. & $\begin{array}{c}\text { Село } \\
\text { Колюбакино }\end{array}$ & $\begin{array}{c}\text { Рождества } \\
\text { Богородицы }\end{array}$ & $\begin{array}{c}\text { Село } \\
\text { Колюбакино }\end{array}$ & $\begin{array}{c}\text { Село } \\
\text { Колюбакино }\end{array}$ & $\begin{array}{c}\text { Село } \\
\text { Рождествено. } \\
\text { Село } \\
\text { Колюбакино } \\
\end{array}$ & - & $\begin{array}{c}\text { Село } \\
\text { Рожествено }\end{array}$ & $\begin{array}{c}\text { Село } \\
\text { Колибякино }\end{array}$ & $\begin{array}{c}\text { Село } \\
\text { Колюбакино }\end{array}$ \\
\hline 9. & $\begin{array}{c}\text { Погост } \\
\text { Кремиченский }\end{array}$ & Покровский & $\begin{array}{c}\text { «Церковь } \\
\text { Покрова... в } \\
\text { Кремичне» } \\
\end{array}$ & $\begin{array}{c}\text { Погост } \\
\text { Кремиченский }\end{array}$ & $\begin{array}{c}\text { Погост } \\
\text { Кремиченский }\end{array}$ & - & $\begin{array}{c}\text { Погост } \\
\text { Покровской }\end{array}$ & $\begin{array}{c}\text { Погост } \\
\text { Кремишня }\end{array}$ & $\begin{array}{c}\text { Село Креншиня } \\
\text { (Явная ошибка } \\
\text { написания) } \\
\end{array}$ \\
\hline 10. & $\begin{array}{c}\text { Погост } \\
\text { Крестовоздви- } \\
\text { женский }\end{array}$ & $\begin{array}{c}\text { Воздвиженский } \\
\text { (Крестовоздви- } \\
\text { женский) }\end{array}$ & $\begin{array}{c}\text { Погост с } \\
\text { Храмом } \\
\text { «Всемирное } \\
\text { Воздвижение» }\end{array}$ & $\begin{array}{c}\text { Церковная земля. } \\
\text { Погост Кресто- } \\
\text { воздвиженский }\end{array}$ & $\begin{array}{c}\text { Погост } \\
\text { Крестовоздви- } \\
\text { женский }\end{array}$ & $\begin{array}{c}\text { «Пустошь } \\
\text { Здвиженская } \\
\text { церковная» }\end{array}$ & $\begin{array}{c}\text { Крестовоздви- } \\
\text { женский } \\
\text { погост }\end{array}$ & $\begin{array}{c}\text { Погост } \\
\text { Воздвиженский }\end{array}$ & $\begin{array}{c}\text { Село «Погост } \\
\text { Крестовоздви- } \\
\text { женский» }\end{array}$ \\
\hline 11. & $\begin{array}{c}\text { Село } \\
\text { Михайловское }\end{array}$ & $\begin{array}{c}\text { Архангело- } \\
\text { Михайловский }\end{array}$ & $\begin{array}{c}\text { Село } \\
\text { Михайловское }\end{array}$ & \begin{tabular}{|c|} 
Село Михайлов- \\
ское (Тростен- \\
ского стана) \\
\end{tabular} & $\begin{array}{c}\text { Село } \\
\text { Михайловское }\end{array}$ & $\begin{array}{c}\text { Село } \\
\text { Михайловское }\end{array}$ & $\begin{array}{c}\text { Село } \\
\text { Михайловское }\end{array}$ & $\begin{array}{c}\text { Село } \\
\text { Михайловское }\end{array}$ & $\begin{array}{c}\text { Село } \\
\text { Михайловское }\end{array}$ \\
\hline 12. & $\begin{array}{c}\text { Село } \\
\text { Онуфриево } \\
\text { (Ануфриево) } \\
\end{array}$ & Успенский & $\begin{array}{c}\text { Вотчина } \\
\text { Онуфриева } \\
\text { монастыря } \\
\end{array}$ & \begin{tabular}{|c|} 
Монастырская \\
слобода Онуфри- \\
евой пустыни \\
\end{tabular} & $\begin{array}{c}\text { Село } \\
\text { Онуфриево }\end{array}$ & $\begin{array}{c}\text { «Монастырь } \\
\text { Анофреевской» }\end{array}$ & $\begin{array}{c}\text { Село } \\
\text { Ануфриево }\end{array}$ & $\begin{array}{c}\text { Село } \\
\text { Анофриево }\end{array}$ & $\begin{array}{c}\text { Село } \\
\text { Онуфриево }\end{array}$ \\
\hline 13. & $\begin{array}{c}\text { Село Поречье } \\
\text { (на реке } \\
\text { Москве) }\end{array}$ & Казанский & $\begin{array}{c}\text { Нет } \\
\text { сведений }\end{array}$ & - & $\begin{array}{c}\text { Село } \\
\text { Поречье }\end{array}$ & - & $\begin{array}{l}\text { Сельцо } \\
\text { Поречье }\end{array}$ & $\begin{array}{c}\text { Село } \\
\text { Поречье }\end{array}$ & $\begin{array}{c}\text { Село } \\
\text { Поречье }\end{array}$ \\
\hline \multirow[b]{2}{*}{14.} & $\begin{array}{c}\text { Село } \\
\text { Полуехтово } \\
\text { (Полуектово, } \\
\text { Полуэктово) } \\
\end{array}$ & $\begin{array}{l}\text { Трёхсвяти- } \\
\text { тельский }\end{array}$ & $\begin{array}{c}\text { «Сельцо } \\
\text { Полуехтово } \\
\text { при селе } \\
\text { Покровском» }\end{array}$ & \begin{tabular}{|c|} 
Сельцо \\
Полуехтово \\
(Волости Юрьева \\
Слобода) \\
\end{tabular} & $\begin{array}{c}\text { Село } \\
\text { Полуехтово }\end{array}$ & - & $\begin{array}{c}\text { Сельцо } \\
\text { Полуехтово }\end{array}$ & $\begin{array}{c}\text { Село } \\
\text { Полуэктова }\end{array}$ & $\begin{array}{c}\text { Село } \\
\text { Полуэхтово }\end{array}$ \\
\hline & - & Покровский & $\begin{array}{c}\text { Село } \\
\text { Покровское }\end{array}$ & $\begin{array}{c}\text { Село } \\
\text { Покровское }\end{array}$ & \begin{tabular}{|c|} 
Село Покровское, \\
Покровское \\
(Орлова), \\
Село Покровское \\
(Долгорукова). \\
Дер. Покровское \\
\end{tabular} & - & $\begin{array}{c}\text { Село } \\
\text { Покровское }\end{array}$ & $\begin{array}{c}\text { Деревня } \\
\text { Покровское }\end{array}$ & $\begin{array}{l}\text { Деревня } \\
\text { «Покров» }\end{array}$ \\
\hline 15. & $\begin{array}{c}\text { Село } \\
\text { Покровское } \\
\text { (Шереметева) }\end{array}$ & Покровский & $\begin{array}{c}\text { Нет } \\
\text { сведений }\end{array}$ & $\mid \begin{array}{c}\text { Село Покровское } \\
\text { (Тростенского } \\
\text { стана) }\end{array}$ & $\begin{array}{c}\text { Село } \\
\text { Покровское }\end{array}$ & $\begin{array}{c}\text { Село } \\
\text { Покровское }\end{array}$ & $\begin{array}{c}\text { Село } \\
\text { Покровское }\end{array}$ & $\begin{array}{c}\text { Село } \\
\text { Покровское }\end{array}$ & $\begin{array}{c}\text { Село } \\
\text { Покровское }\end{array}$ \\
\hline 16. & $\begin{array}{c}\text { Село } \\
\text { Сляднево }\end{array}$ & $\begin{array}{c}\text { Преображения } \\
\text { Спасова }\end{array}$ & $\begin{array}{c}\text { Сельцо, } \\
\text { пустошь } \\
\text { Сляднево }\end{array}$ & $\begin{array}{c}\text { Пустошь, сельцо } \\
\text { Сляднево }\end{array}$ & $\begin{array}{l}\text { Село Сляднево, } \\
\text { Спасское тоже }\end{array}$ & - & $\begin{array}{c}\text { Село } \\
\text { Сляднево }\end{array}$ & $\begin{array}{c}\text { Село } \\
\text { Сляднево }\end{array}$ & $\begin{array}{c}\text { Село } \\
\text { Сляднево }\end{array}$ \\
\hline
\end{tabular}




\begin{tabular}{|c|c|c|c|c|c|c|c|c|c|}
\hline 17. & $\begin{array}{c}\text { Село } \\
\text { Спасское }\end{array}$ & $\begin{array}{c}\text { Преображения } \\
\text { Спасова }\end{array}$ & $\begin{array}{c}\text { Село } \\
\text { Спасское }\end{array}$ & $\begin{array}{c}\text { Село Спасское } \\
\text { (Льняникова } \\
\text { стана) }\end{array}$ & $\begin{array}{c}\text { Село } \\
\text { Спасское }\end{array}$ & $\begin{array}{c}\text { Село } \\
\text { «Спаское» }\end{array}$ & $\begin{array}{c}\text { Село } \\
\text { Спасское }\end{array}$ & $\begin{array}{c}\text { Село } \\
\text { Спасское }\end{array}$ & $\begin{array}{c}\text { Село } \\
\text { Спасское }\end{array}$ \\
\hline 18. & $\begin{array}{c}\text { Село } \\
\text { Тёплое }\end{array}$ & Знаменский & $\begin{array}{l}\text { Деревня } \\
\text { Тёплое }\end{array}$ & $\begin{array}{l}\text { Пустошь, дерев- } \\
\text { ня, село Тёплое }\end{array}$ & $\begin{array}{c}\text { Село } \\
\text { Тёплое }\end{array}$ & - & $\begin{array}{c}\text { Село } \\
\text { Тёплое }\end{array}$ & $\begin{array}{c}\text { Село } \\
\text { Тёплое }\end{array}$ & $\begin{array}{c}\text { Село } \\
\text { Тёплое }\end{array}$ \\
\hline \multicolumn{10}{|c|}{ Сёла, названия которых изменялись в течение рассматриваемого периода и на которых была выполнена апробация методики идентификации } \\
\hline 1. & $\begin{array}{c}\text { Село } \\
\text { Аннино }\end{array}$ & Знаменский & $\begin{array}{c}\text { Село Аннино, } \\
\text { Вельяминово } \\
\text { тоже } \\
\end{array}$ & $\begin{array}{c}\text { Село } \\
\text { Знаменское, } \\
\text { Аннино тоже } \\
\end{array}$ & $\begin{array}{c}\text { Село } \\
\text { Аннино }\end{array}$ & - & $\begin{array}{c}\text { Село } \\
\text { Аннино }\end{array}$ & $\begin{array}{c}\text { Село } \\
\text { Аннино }\end{array}$ & $\begin{array}{c}\text { Село } \\
\text { Аннино }\end{array}$ \\
\hline 2. & $\begin{array}{c}\text { Село } \\
\text { Архангельское, } \\
\text { Мытники тоже }\end{array}$ & $\begin{array}{c}\text { Первый - } \\
\text { Архистратига } \\
\text { Гавриила. } \\
\text { Второй - } \\
\text { Рождества } \\
\text { Христова } \\
\end{array}$ & $\begin{array}{c}\text { Сельцо } \\
\text { Мытниково }\end{array}$ & $\begin{array}{c}\text { Сельцо } \\
\text { Мытники }\end{array}$ & \begin{tabular}{|c|} 
Село Архангель- \\
ское (при Храме \\
Архангельском). \\
Село Мытниково \\
(при Храме \\
Рождественском) \\
\end{tabular} & - & $\begin{array}{c}\text { Село } \\
\text { Архангельское }\end{array}$ & $\begin{array}{c}\text { Село } \\
\text { Мытники }\end{array}$ & $\begin{array}{c}\text { Село } \\
\text { Мытники }\end{array}$ \\
\hline 3. & $\begin{array}{c}\text { Село } \\
\text { Брынково }\end{array}$ & $\begin{array}{c}\text { Первый - } \\
\text { Георгиевский. } \\
\text { Второй - } \\
\text { Казанский } \\
\end{array}$ & \begin{tabular}{|c|} 
Сельцо, село \\
Брынково, \\
Матвейцово \\
тоже \\
\end{tabular} & \begin{tabular}{|c|} 
Село Брынково, \\
Матвейцово \\
тоже \\
\end{tabular} & \begin{tabular}{|c|} 
Село \\
Богородское, \\
Брынково и \\
Матвейцово тоже
\end{tabular} & $\begin{array}{c}\text { Село } \\
\text { Брынково }\end{array}$ & $\begin{array}{c}\text { Село } \\
\text { Брынково }\end{array}$ & $\begin{array}{c}\text { Село } \\
\text { Бринькова }\end{array}$ & $\begin{array}{c}\text { Село } \\
\text { Брыньково }\end{array}$ \\
\hline 4. & $\begin{array}{c}\text { Село } \\
\text { Введенское-- } \\
\text { Клементьево }\end{array}$ & $\begin{array}{c}\text { Первый —- } \\
\text { Никольский. } \\
\text { Второй —- } \\
\text { Введенский }\end{array}$ & $\begin{array}{c}\text { «ерковь в при- } \\
\text { сёлке Клемен- } \\
\text { тьеве, припи- } \\
\text { санном к с. Ше- } \\
\text { боршину» } \\
\end{array}$ & $\begin{array}{c}\text { Село } \\
\text { Клементьево. } \\
\text { Село } \\
\text { Введенское }\end{array}$ & \begin{tabular}{|} 
Село Клементь- \\
ево. \\
Село Введенское \\
(Клементьево). \\
Село Введенское \\
\end{tabular} & - & $\begin{array}{c}\text { Село } \\
\text { «Веденское» }\end{array}$ & $\begin{array}{c}\text { Село } \\
\text { Введенское-- } \\
\text { Клементьево }\end{array}$ & $\begin{array}{c}\text { Село } \\
\text { Клементьево }\end{array}$ \\
\hline 5. & $\begin{array}{c}\text { Погост } \\
\text { Георгиевский }\end{array}$ & $\begin{array}{c}\text { Первый - } \\
\text { Георгиевский. } \\
\text { Второй - } \\
\text { Троицкий }\end{array}$ & $\begin{array}{c}\text { Погост } \\
\text { Георгиевский }\end{array}$ & \begin{tabular}{|c|} 
Погост Георги- \\
евский. \\
Церковная Ге- \\
орг. земля. \\
«Погост \\
Троицкой» \\
\end{tabular} & $\begin{array}{c}\text { Погост } \\
\text { Троицкой. } \\
\text { Село } \\
\text { Георгиевское }\end{array}$ & - & $\begin{array}{c}\text { Село } \\
\text { Троицкое }\end{array}$ & $\begin{array}{c}\text { Погост } \\
\text { Георгиевский }\end{array}$ & $\begin{array}{c}\text { Село } \\
\text { «огост } \\
\text { Георгиевский» }\end{array}$ \\
\hline 6. & $\begin{array}{c}\text { Село } \\
\text { Горбово- } \\
\text { Мосальское }\end{array}$ & $\begin{array}{c}\text { Одигитриевский } \\
\text { (Смоленский) }\end{array}$ & $\begin{array}{l}\text { Деревня } \\
\text { Горбово }\end{array}$ & $\begin{array}{l}\text { Пустошь } \\
\text { Горбово }\end{array}$ & $\begin{array}{c}\text { Сельцо Горбово; } \\
\text { Одигитриевское; } \\
\text { Одигитриевское, } \\
\text { Горбово тоже }\end{array}$ & - & $\begin{array}{c}\text { Село } \\
\text { Одигитриевское }\end{array}$ & $\begin{array}{c}\text { Село } \\
\text { Горбово }\end{array}$ & $\begin{array}{c}\text { Село } \\
\text { Горбово }\end{array}$ \\
\hline 7. & $\begin{array}{c}\text { Село } \\
\text { Горбово- } \\
\text { Хованское }\end{array}$ & Казанский & - & $\begin{array}{c}\text { Деревня, сельцо } \\
\text { Горбово. Село } \\
\text { Богородицкое }\end{array}$ & $\begin{array}{c}\text { Село } \\
\text { Горбово }\end{array}$ & $\begin{array}{c}\text { «Село } \\
\text { Богородицкое» }\end{array}$ & $\begin{array}{c}\text { Село } \\
\text { Богородское }\end{array}$ & $\begin{array}{c}\text { Село } \\
\text { Горбово } \\
\text { (Богородское) } \\
\end{array}$ & $\begin{array}{c}\text { Село } \\
\text { Богородское }\end{array}$ \\
\hline
\end{tabular}




\begin{tabular}{|c|c|c|c|c|c|c|c|c|c|}
\hline \multirow[t]{2}{*}{8.} & \multirow{2}{*}{$\begin{array}{c}\text { Село } \\
\text { Дуброво }\end{array}$} & $\begin{array}{c}\text { Происхождения } \\
\text { Честных Древ } \\
\text { Всемилостивог } \\
\text { о Спаса } \\
\text { (Спасский) } \\
\end{array}$ & $\begin{array}{c}\text { Погост } \\
\text { Воскресения } \\
\text { Христова } \\
\text { (Дубровка) }\end{array}$ & $\begin{array}{c}\text { Воскресенская } \\
\text { церковная земля } \\
\text { в Дубровичах. } \\
\text { Сельцо Дуброва }\end{array}$ & $\begin{array}{c}\text { Село Дуброва, } \\
\text { редко - } \\
\text { Спасское }\end{array}$ & $\begin{array}{c}\text { Сельцо } \\
\text { Дубровки }\end{array}$ & \multirow{2}{*}{$\begin{array}{c}\text { Село } \\
\text { Спасское }\end{array}$} & \multirow{2}{*}{$\begin{array}{c}\text { Село } \\
\text { Дуброва }\end{array}$} & \multirow{2}{*}{$\begin{array}{c}\text { Село } \\
\text { Дуброва }\end{array}$} \\
\hline & & $\begin{array}{c}\text { Воскресенский } \\
\text { (утрачен) }\end{array}$ & $\begin{array}{l}\text { Сельцо Щер- } \\
\text { бинино, Вос- } \\
\text { кресенское } \\
\text { тоже (на речке } \\
\text { Мешковке) } \\
\end{array}$ & $\begin{array}{c}\text { Пустошь } \\
\text { Щербинино. } \\
\text { Воскресенская } \\
\text { земля в } \\
\text { Дубровичах } \\
\end{array}$ & $\begin{array}{c}\text { Пустошь } \\
\text { Щербинино }\end{array}$ & $\begin{array}{c}\text { «Кладбище } \\
\text { Воскресенское } \\
\text { и два двора } \\
\text { крестьянских» }\end{array}$ & & & \\
\hline 9. & $\begin{array}{c}\text { Село } \\
\text { Никольское- } \\
\text { Гагарино } \\
\end{array}$ & Никольский & $\begin{array}{c}\text { Нет } \\
\text { сведений }\end{array}$ & $\begin{array}{c}\text { Село } \\
\text { Никольское }\end{array}$ & $\begin{array}{c}\text { Село } \\
\text { Никольское, } \\
\text { что Гагарина } \\
\end{array}$ & $\begin{array}{c}\text { Село } \\
\text { Никольское }\end{array}$ & $\begin{array}{c}\text { Село } \\
\text { Никольское }\end{array}$ & $\begin{array}{c}\text { Село } \\
\text { Никольское }\end{array}$ & $\begin{array}{c}\text { Село } \\
\text { Никольское- } \\
\text { Гагарино } \\
\end{array}$ \\
\hline 10. & $\begin{array}{c}\text { Село } \\
\text { Никольское-- } \\
\text { Долгоруково }\end{array}$ & Никольский & $\begin{array}{c}\text { Село } \\
\text { Никольское }\end{array}$ & $\begin{array}{c}\text { Сельцо } \\
\text { Никольское. } \\
\text { Село } \\
\text { Никольское, } \\
\text { Поскочино тоже }\end{array}$ & $\begin{array}{c}\text { Село } \\
\text { Никольское. } \\
\text { Село } \\
\text { Никольское }\end{array}$ & $\begin{array}{c}\text { На месте села } \\
\text { не указано } \\
\text { каких-либо } \\
\text { объектов }\end{array}$ & $\begin{array}{c}\text { Село } \\
\text { Никольское }\end{array}$ & $\begin{array}{c}\text { Село } \\
\text { Никольское }\end{array}$ & $\begin{array}{c}\text { Село } \\
\text { Долгоруково }\end{array}$ \\
\hline 11. & $\begin{array}{c}\text { Село } \\
\text { Дьяково }\end{array}$ & $\begin{array}{c}\text { Борисо- } \\
\text { глебский }\end{array}$ & $\begin{array}{c}\text { Село } \\
\text { Скорево }\end{array}$ & $\begin{array}{l}\text { Село Скорево, } \\
\text { Дьяково тоже }\end{array}$ & $\begin{array}{c}\text { Село } \\
\text { Дьяково }\end{array}$ & $\begin{array}{c}\text { Село } \\
\text { Дьяково }\end{array}$ & $\begin{array}{c}\text { Село } \\
\text { Дьяково }\end{array}$ & $\begin{array}{c}\text { Село } \\
\text { Дьякова }\end{array}$ & $\begin{array}{c}\text { Село } \\
\text { Дьяково }\end{array}$ \\
\hline 12. & $\begin{array}{c}\text { Село } \\
\text { Ивойлово }\end{array}$ & $\begin{array}{c}\text { Первый - } \\
\text { Никольский. } \\
\text { Второй - } \\
\text { Воскресенский }\end{array}$ & $\begin{array}{c}\text { Село } \\
\text { Федосово }\end{array}$ & $\begin{array}{c}\text { Село Ивойлово, } \\
\text { Федосово тоже. } \\
\text { Село Ивойлово, } \\
\text { Воскресенское } \\
\text { тоже }\end{array}$ & $\begin{array}{c}\text { Село } \\
\text { Ивойлово }\end{array}$ & 一 & $\begin{array}{c}\text { Село } \\
\text { Ивойлово }\end{array}$ & $\begin{array}{c}\text { Село } \\
\text { Ивойлово }\end{array}$ & $\begin{array}{c}\text { Село } \\
\text { Ивойлово }\end{array}$ \\
\hline \multirow[t]{2}{*}{13.} & $\begin{array}{c}\text { Село } \\
\text { Каменка }\end{array}$ & $\begin{array}{c}\text { Освящение } \\
\text { храма не } \\
\text { известно }\end{array}$ & $\begin{array}{c}\text { Село, пустошь } \\
\text { Каменка }\end{array}$ & $\begin{array}{l}\text { Деревня } \\
\text { Каменка }\end{array}$ & \begin{tabular}{|c|} 
Деревня \\
Каменка \\
(Вероятно, про- \\
изошло слияние с \\
селом Богослов- \\
ским). Село \\
Богословское, \\
Каменка тоже \\
\end{tabular} & - & \multirow[t]{2}{*}{$\begin{array}{c}\text { Село } \\
\text { Богословское }\end{array}$} & \multirow[t]{2}{*}{$\begin{array}{c}\text { Село } \\
\text { Каменка }\end{array}$} & \multirow[t]{2}{*}{$\begin{array}{c}\text { Село } \\
\text { Каменка }\end{array}$} \\
\hline & & $\begin{array}{c}\text { Иоанно- } \\
\text { Богословский }\end{array}$ & - & $\begin{array}{c}\text { Сельцо, } \\
\text { пустошь } \\
\text { Дорки } \\
\end{array}$ & \begin{tabular}{|c|} 
Село \\
$\begin{array}{c}\text { Богословское, } \\
\text { Дорки тоже }\end{array}$ \\
\end{tabular} & 一 & & & \\
\hline
\end{tabular}




\begin{tabular}{|c|c|c|c|c|c|c|c|c|c|}
\hline 14. & $\begin{array}{c}\text { Село } \\
\text { Картино }\end{array}$ & Успенский & $\begin{array}{c}\text { «Церковь } \\
\text { Успения на } \\
\text { погосте» }\end{array}$ & \begin{tabular}{|c|} 
Пустошь, церков- \\
ная земля, село \\
Картино \\
\end{tabular} & $\begin{array}{c}\text { Село } \\
\text { Картин Погост }\end{array}$ & - & $\begin{array}{l}\text { Погост } \\
\text { Картин }\end{array}$ & $\begin{array}{c}\text { Погост } \\
\text { Картино }\end{array}$ & $\begin{array}{c}\text { Село } \\
\text { Картин погост }\end{array}$ \\
\hline 15. & $\begin{array}{c}\text { Село } \\
\text { Кожино }\end{array}$ & Воскресенский & - & $\begin{array}{c}\text { Сельцо Кожино. } \\
\text { Село } \\
\text { Воскресенское } \\
\end{array}$ & $\begin{array}{c}\text { Село } \\
\text { Кожино }\end{array}$ & - & $\begin{array}{c}\text { Село } \\
\text { Кожино }\end{array}$ & $\begin{array}{c}\text { Село } \\
\text { Кожино }\end{array}$ & $\begin{array}{c}\text { Село } \\
\text { Кожино }\end{array}$ \\
\hline 16. & $\begin{array}{c}\text { Село } \\
\text { Козлово }\end{array}$ & Флоролаврский & $\begin{array}{c}\text { Село } \\
\text { Семёновское }\end{array}$ & $\begin{array}{c}\text { Сельцо Козлово; } \\
\text { село } \\
\text { Семёновское, } \\
\text { Козлово тоже } \\
\end{array}$ & $\begin{array}{c}\text { Село } \\
\text { Козлово }\end{array}$ & - & $\begin{array}{c}\text { Село } \\
\text { Козлово }\end{array}$ & $\begin{array}{c}\text { Село } \\
\text { Козлово }\end{array}$ & $\begin{array}{c}\text { Село } \\
\text { Козлово }\end{array}$ \\
\hline 17. & $\begin{array}{c}\text { Село Комлево; } \\
\text { Знаменское, } \\
\text { Комлево тоже } \\
\end{array}$ & Знаменский & - & - & $\begin{array}{c}\text { Сельцо, село } \\
\text { Комлево }\end{array}$ & - & $\begin{array}{c}\text { Сельцо } \\
\text { Комлево }\end{array}$ & $\begin{array}{c}\text { Село } \\
\text { Комлево }\end{array}$ & $\begin{array}{c}\text { Село } \\
\text { Комлево }\end{array}$ \\
\hline 18. & $\begin{array}{c}\text { Село } \\
\text { Крымское }\end{array}$ & $\begin{array}{c}\text { Первый - Ни- } \\
\text { кольский. Вто- } \\
\text { рой - } \\
\text { Преображен- } \\
\text { ский }\end{array}$ & $\begin{array}{c}\text { Деревня } \\
\text { Крымское Дво- } \\
\text { рище. } \\
\text { Близ неё- } \\
\text { Храм Николь- } \\
\text { ский }\end{array}$ & \begin{tabular}{|} 
Пустошь, деревня \\
Крымское \\
Дворище (Мити- \\
нодворское). Село \\
Преображенское \\
(Угожского \\
стана)
\end{tabular} & $\begin{array}{c}\text { Село } \\
\text { Крымское }\end{array}$ & - & $\begin{array}{c}\text { Сельцо Крым- } \\
\text { ское, } \\
\text { близ него храм }\end{array}$ & $\begin{array}{c}\text { Село } \\
\text { Крымское }\end{array}$ & $\begin{array}{c}\text { Не указано, т.к. } \\
\text { расположено за } \\
\text { обозначенными } \\
\text { на схеме } \\
\text { границами уезда }\end{array}$ \\
\hline 19. & $\begin{array}{c}\text { Село } \\
\text { Лужки }\end{array}$ & Николаевский & $\begin{array}{l}\text { «Погост..., а } \\
\text { на погосте } \\
\text { Церковь } \\
\text { Николы } \\
\text { Чудотворца» } \\
\end{array}$ & $\begin{array}{c}\text { Никольская } \\
\text { церковная земля. } \\
\text { Погост, село } \\
\text { Лужки }\end{array}$ & $\begin{array}{c}\text { Лужки } \\
\text { (без указания } \\
\text { типа } \\
\text { землевладения) }\end{array}$ & $\begin{array}{c}\text { «Церковь } \\
\text { Николы } \\
\text { Чудотворца на } \\
\text { погосте в } \\
\text { Лушках» } \\
\end{array}$ & $\begin{array}{c}\text { Погост } \\
\text { Никольской }\end{array}$ & $\begin{array}{l}\text { Погост } \\
\text { Лужки }\end{array}$ & $\begin{array}{c}\text { Село } \\
\text { Лужки }\end{array}$ \\
\hline 20. & $\begin{array}{c}\text { Село } \\
\text { Рождествено-- } \\
\text { Новиково } \\
\end{array}$ & $\begin{array}{c}\text { Рождественский } \\
\text { (Рождества } \\
\text { Христова) } \\
\end{array}$ & $\begin{array}{c}\text { Село Марково } \\
\text { (Скирманов- } \\
\text { ского стана) } \\
\end{array}$ & $\begin{array}{c}\text { Село } \\
\text { Рождествено, } \\
\text { Марково тоже }\end{array}$ & $\begin{array}{c}\text { Село } \\
\text { Рождественское } \\
\text { (Рождествено) } \\
\end{array}$ & - & $\begin{array}{c}\text { Село } \\
\text { Рожествено }\end{array}$ & $\begin{array}{c}\text { Село } \\
\text { Рожественское }\end{array}$ & $\begin{array}{c}\text { Село } \\
\text { Рожествино }\end{array}$ \\
\hline \multirow{2}{*}{21.} & \multirow{2}{*}{$\begin{array}{c}\text { Село } \\
\text { Старая Руза }\end{array}$} & $\begin{array}{c}\text { Преображен- } \\
\text { ский }\end{array}$ & $\begin{array}{c}\text { Храм } \\
\text { упразднён } \\
\text { по ветхости }\end{array}$ & \begin{tabular}{|c|} 
Погост \\
Спасский. \\
Церковная земля \\
в селе Старая \\
Руза \\
\end{tabular} & $\begin{array}{c}- \\
\text { (В документах } \\
\text { не } \\
\text { упоминается) }\end{array}$ & - & $\begin{array}{c}\text { Село } \\
\text { Старая Руза }\end{array}$ & \multirow{2}{*}{$\begin{array}{c}\text { Село } \\
\text { Старая Руза }\end{array}$} & \multirow{2}{*}{$\begin{array}{c}\text { Село } \\
\text { Старая Руза }\end{array}$} \\
\hline & & $\begin{array}{c}\text { Рождества } \\
\text { Богородицы }\end{array}$ & $\begin{array}{c}\text { Основан } \\
\text { Храм } \\
\text { Рождества } \\
\text { Богородицы }\end{array}$ & $\begin{array}{l}\text { Село, погост } \\
\text { Старая Руза }\end{array}$ & $\begin{array}{c}\text { Погост Старой } \\
\text { Рузы на } \\
\text { территории села }\end{array}$ & - & $\begin{array}{c}\text { «Погост } \\
\text { Рождествен- } \\
\text { ской» иุеркви }\end{array}$ & & \\
\hline
\end{tabular}




\begin{tabular}{|c|c|c|c|c|c|c|c|c|c|}
\hline \multicolumn{10}{|c|}{$\begin{array}{c}\text { Сёла, сведения о которых удалось обнаружить в документальных источниках } \\
\text { в результате применения апробированной на предыдущем этапе методики }\end{array}$} \\
\hline 1. & $\begin{array}{c}\text { Село } \\
\text { Васильевское }^{1} \\
\text { (Нижне- } \\
\text { васильевское) }\end{array}$ & $\begin{array}{c}\text { Рождества } \\
\text { Богородицы }\end{array}$ & - & $\begin{array}{c}\text { Сельцо, пу- } \\
\text { стошь } \\
\text { Васильевская } \\
\text { (Ижевского } \\
\text { стана) } \\
\end{array}$ & $\begin{array}{l}\text { Сельцо, село } \\
\text { Васильевское }\end{array}$ & - & $\begin{array}{c}\text { Село } \\
\text { Васильевское }\end{array}$ & $\begin{array}{c}\text { Село } \\
\text { Васильевское }\end{array}$ & $\begin{array}{c}\text { Село } \\
\text { Васильевское }\end{array}$ \\
\hline 2. & $\begin{array}{c}\text { Село } \\
\text { Назарьево }^{2} \\
\text { (Назарово) }\end{array}$ & Троицкий & $\begin{array}{c}\text { Нет } \\
\text { сведений }\end{array}$ & $\begin{array}{c}\text { Деревня, пу- } \\
\text { стошь, сельцо, } \\
\text { село Назарово } \\
\text { (Ижевского } \\
\text { стана) } \\
\end{array}$ & $\begin{array}{c}\text { Село Назарово } \\
\text { (Троицкое-- } \\
\text { Назарово) }\end{array}$ & - & $\begin{array}{c}\text { Село } \\
\text { Троицкое }\end{array}$ & $\begin{array}{c}\text { Село } \\
\text { Назарово }\end{array}$ & $\begin{array}{c}\text { Село } \\
\text { Назарово }\end{array}$ \\
\hline \multirow[b]{2}{*}{3.} & \multirow{2}{*}{$\begin{array}{c}\text { Село } \\
\text { Петрово } \\
\text { (Мансурово) }\end{array}$} & $\begin{array}{c}\text { Похвалы } \\
\text { Пресвятой } \\
\text { Богородицы }\end{array}$ & $\begin{array}{l}\text { Сельцо } \\
\text { Петрово }\end{array}$ & $\begin{array}{c}\text { Сельцо, село } \\
\text { Петрово } \\
\text { (Сурожского } \\
\text { стана) } \\
\end{array}$ & $\begin{array}{c}\text { Село } \\
\text { Петрово }\end{array}$ & $\begin{array}{c}\text { Село } \\
\text { Петровское }\end{array}$ & $\begin{array}{c}\text { Село } \\
\text { Петрово }\end{array}$ & $\begin{array}{l}\text { Деревня } \\
\text { Петрово }\end{array}$ & $\begin{array}{c}\text { Село } \\
\text { Петрово }\end{array}$ \\
\hline & & Никольский & $\begin{array}{c}\text { Село } \\
\text { Мансурово }\end{array}$ & $\begin{array}{c}\text { Село, сельцо и } \\
\text { вновь село } \\
\text { Мансурово } \\
\text { (Сурожского } \\
\text { стана) } \\
\end{array}$ & $\begin{array}{l}\text { Деревня Манс- } \\
\text { урово, рядом } \\
\text { «погост Ни- } \\
\text { кольской» }\end{array}$ & - & $\begin{array}{c}\text { Село } \\
\text { Мансурово }\end{array}$ & $\begin{array}{c}\text { Деревня } \\
\text { Мансурова и } \\
\text { «погост Ни- } \\
\text { кольской» }\end{array}$ & $\begin{array}{c}\text { Деревня } \\
\text { Мансурова }\end{array}$ \\
\hline 4. & $\begin{array}{c}\text { Село } \\
\text { Пречистенское } \\
\text { (Пречистое) }\end{array}$ & Успенский & $\begin{array}{c}\text { Село } \\
\text { Поповское } \\
\text { (Ижевского } \\
\text { стана. } \\
\text { На реке Ну- } \\
\text { доль) } \\
\end{array}$ & $\begin{array}{c}\text { Пустошь По- } \\
\text { повское. Село } \\
\text { Пречистенское, } \\
\text { Поповское } \\
\text { тоже }\end{array}$ & $\begin{array}{c}\text { Село } \\
\text { Пречистенское, } \\
\text { Поповское } \\
\text { тоже }\end{array}$ & - & $\begin{array}{c}\text { Село } \\
\text { Пречистенское }\end{array}$ & $\begin{array}{c}\text { Село } \\
\text { Пречистое }\end{array}$ & $\begin{array}{c}\text { Село } \\
\text { Пречистенское }\end{array}$ \\
\hline
\end{tabular}

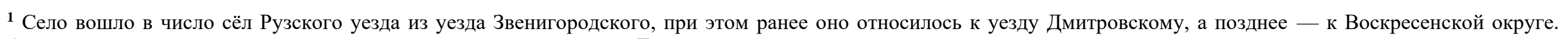
Согласно церковно-территориальному делению село относилось к Дмитровской десятине

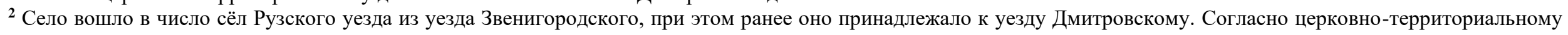
делению село относилось к Дмитровской десятине

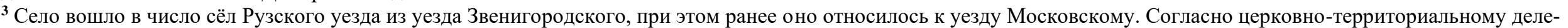
нию на протяжении длительного времени относилось к Загородской десятине

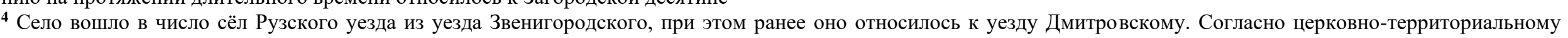
делению село относилось к Дмитровской, а позднее — к Волоколамской десятинам 


\begin{tabular}{|c|c|c|c|c|c|c|c|c|c|}
\hline 5. & $\begin{array}{c}\text { Село } \\
\text { Савельево }\end{array}$ & $\begin{array}{c}\text { Рождества } \\
\text { Богородицы } \\
\text { (Богоро- } \\
\text { дицкий) }\end{array}$ & - & $\begin{array}{c}\text { Село Савельево } \\
\text { (Ижевского, ра- } \\
\text { нее - Мушков- } \\
\text { ского стана) }\end{array}$ & $\begin{array}{c}\text { Село } \\
\text { Савельево }\end{array}$ & - & $\begin{array}{c}\text { Село } \\
\text { Савельево }\end{array}$ & $\begin{array}{c}\text { Село } \\
\text { Савельево }\end{array}$ & $\begin{array}{c}\text { Село } \\
\text { Савельево }\end{array}$ \\
\hline \multirow{3}{*}{6.} & \multirow{3}{*}{$\begin{array}{c}\text { Село Юркиноㄹ } \\
\text { (Рожествено Юр- } \\
\text { кино, Рожде- } \\
\text { ствено- } \\
\text { Татищево) }\end{array}$} & \multirow{3}{*}{$\begin{array}{c}\text { Рождества } \\
\text { Христова } \\
\text { (Рождествен- } \\
\text { ский) }\end{array}$} & $\begin{array}{c}\text { Рождествен- } \\
\text { ский погост на } \\
\text { речке Малая } \\
\text { Истрица } \\
\end{array}$ & $\begin{array}{c}\text { Погост церкви } \\
\text { Рождества } \\
\text { Христова }\end{array}$ & $\begin{array}{c}\text { «огост..., что } \\
\text { слывёт село } \\
\text { Юркино» }\end{array}$ & - & $\begin{array}{c}\text { Погост } \\
\text { «Рождественской» } \\
\text { иеркви }\end{array}$ & - & - \\
\hline & & & $\begin{array}{l}\text { Село, сельцо } \\
\text { Юркино }\end{array}$ & $\begin{array}{c}\text { «Сельцо Юркино } \\
\text { при деревне Та- } \\
\text { тищевой» }\end{array}$ & $\begin{array}{c}\text { Село } \\
\text { Рожествено- } \\
\text { Юркино } \\
\end{array}$ & - & $\begin{array}{l}\text { Сельцо } \\
\text { Юркино }\end{array}$ & $\begin{array}{c}\text { Село } \\
\text { Рождествен- } \\
\text { ское-Юркино } \\
\end{array}$ & $\begin{array}{c}\text { Село } \\
\text { Юркино }\end{array}$ \\
\hline & & & $\begin{array}{c}\text { Деревня } \\
\text { Татищево }\end{array}$ & $\begin{array}{c}\text { Деревня, сельцо } \\
\text { Татищево }\end{array}$ & $\begin{array}{c}\text { Деревня, село } \\
\text { Татищево, } \\
\text { «.. оно же и } \\
\text { Рожествено» }\end{array}$ & - & $\begin{array}{c}\text { Село } \\
\text { Татищево }\end{array}$ & $\begin{array}{c}\text { Село } \\
\text { Рождествен- } \\
\text { ское-Татищев } \\
\text { о } \\
\end{array}$ & $\begin{array}{c}\text { Деревня } \\
\text { Татищево }\end{array}$ \\
\hline \multicolumn{10}{|c|}{ Сёла, история которых оказалась слишком короткой для использования в целях настоящего исследования } \\
\hline 1. & $\begin{array}{c}\text { Село (с } 1894 \text { г.) } \\
\text { Аббакумова Пу- } \\
\text { стынь } \\
\end{array}$ & $\begin{array}{c}\text { Святого } \\
\text { Александра } \\
\text { Невского } \\
\end{array}$ & - & - & - & - & - & - & - \\
\hline 2. & $\begin{array}{c}\text { Село (с } 1895 \text { г.) } \\
\text { Настасьино } \\
\end{array}$ & $\begin{array}{c}\text { Николы } \\
\text { Угодника } \\
\end{array}$ & - & $\begin{array}{c}\text { Нет } \\
\text { сведений }\end{array}$ & $\begin{array}{c}\text { Деревня } \\
\text { Настасьина }\end{array}$ & - & $\begin{array}{c}\text { Деревня } \\
\text { Настасьина }\end{array}$ & $\begin{array}{c}\text { Деревня } \\
\text { Настасьина }\end{array}$ & $\begin{array}{c}\text { Деревня } \\
\text { Настасьино } \\
\end{array}$ \\
\hline 3. & $\begin{array}{c}\text { Село (с } 1821 \text { г.) } \\
\text { Нестерово } \\
\text { (на реке Москве) }\end{array}$ & $\begin{array}{l}\text { Преобра- } \\
\text { женский }\end{array}$ & - & $\begin{array}{c}\text { Сельцо } \\
\text { Нестерово }\end{array}$ & $\begin{array}{c}\text { Сельцо } \\
\text { Нестерово }\end{array}$ & - & $\begin{array}{c}\text { Сельцо } \\
\text { Нестерово }\end{array}$ & $\begin{array}{c}\text { Село } \\
\text { Нестерова }\end{array}$ & $\begin{array}{c}\text { Село } \\
\text { Нестерова }\end{array}$ \\
\hline 4. & $\begin{array}{c}\text { Село (с } 1834 \text { г.) } \\
\text { Петровское, (Но- } \\
\text { вопетровское) }\end{array}$ & $\begin{array}{c}\text { Петро- } \\
\text { павловский }\end{array}$ & - & - & $\begin{array}{c}\text { Нет } \\
\text { сведений }\end{array}$ & - & $\begin{array}{c}\text { Сельцо } \\
\text { Петровское } \\
\text { (Ижевского стана) }\end{array}$ & $\begin{array}{c}\text { Сельцо } \\
\text { Петровское }\end{array}$ & $\begin{array}{c}\text { Село } \\
\text { Петровское }\end{array}$ \\
\hline 5. & $\begin{array}{c}\text { Село (с } 1895 \text { г.) } \\
\text { Холм }\end{array}$ & $\begin{array}{c}\text { Александро- } \\
\text { невский }\end{array}$ & - & $\begin{array}{c}\text { Нет } \\
\text { сведений }\end{array}$ & $\begin{array}{c}\text { Деревня } \\
\text { Холм }\end{array}$ & - & $\begin{array}{c}\text { Деревня } \\
\text { Холм }\end{array}$ & $\begin{array}{c}\text { Деревня } \\
\text { Холм }\end{array}$ & $\begin{array}{c}\text { Деревня } \\
\text { Холм }\end{array}$ \\
\hline
\end{tabular}

${ }^{1}$ Село вошло в число сёл Рузского уезда из уезда Звенигородского, при этом ранее оно относилось к уезду Дмитровскому. Согласно церковно-территориальному делению село относилось к Дмитровской, а позднее - к Волоколамской десятинам

2 Село вошло в число сёл Рузского уезда из уезда Звенигородского (при этом часть его ранее располагалась на территории Московского уезда).

Согласно церковно-территориальному делению относилось к Сурожской, а позднее — к Загородской десятинам 
работ свидетельствует о том, что приведённые в таблице статистические значения в значительной мере зависят как от исторических особенностей самих поселений, так и от особенностей территорий, на которых они располагаются. Так, было установлено, что известное освящение храма в наибольшей степени способствуют обеспечению успеха идентификации исключительно при его уникальности и неизменности во времени; известное название стана - при отсутствии поселений с одинаковыми названиями на анализируемой территории, а сведения о владельцах - в случае владельцев, являющихся частными лицами. Например, вследствие того что для территории Звенигородского уезда характерно значительно большее, чем для уезда Рузского, относительное количество сёл, после секуляризации церковных земель, принадлежащих Экономическому ведомству, критерий имущественной принадлежности сёл будет менее эффективным, т.к. часть сёл с одинаковым критерием имущественной принадлежности в Звенигородском уезде значительно больше, чем в уезде Рузском. В силу отмеченного, распределение критериев по их эффективности для различных территорий может значительно меняться.

Присутствующие же в таблице строки с нулевыми значениями успешных случаев выполнения идентификации на обоих этапах настоящего исследования свидетельствует о том, что при проведении представляемого в настоящей статье исследования, выполненного в отношении сёл, их использования не понадобилось. Однако, в силу того что в исторических материалах соответствующие сведения приводятся, и в иных случаях представленные в них критерии показали свою эффективность для поселений и землевладений иных типов, было решено указать их в таблице.

Табл. 2. Сведения о количестве случаев успешной идентификаџии сёл Table 2. Information about the number of cases of successful identification of rural

\begin{tabular}{|c|c|c|c|}
\hline \multirow[t]{2}{*}{ №№ } & \multirow[t]{2}{*}{ Идентификационные критерии } & \multicolumn{2}{|c|}{$\begin{array}{l}\text { Количество успешных иденти- } \\
\text { фикаций сёл с их использова- } \\
\text { нием }\end{array}$} \\
\hline & & \begin{tabular}{|c|} 
На этапе \\
апробирования \\
методики
\end{tabular} & $\begin{array}{l}\text { На этапе } \\
\text { применения } \\
\text { методики }\end{array}$ \\
\hline 1 & 2 & \begin{tabular}{|c|}
3 \\
\end{tabular} & 4 \\
\hline 1. & $\begin{array}{l}\text { Каковы освящение располагавшегося на территории села храма и его } \\
\text { приделов? Оставались ли они неизменными на протяжении рассмат- } \\
\text { риваемого отрезка времени? Если имели место изменения освящений, } \\
\text { то во имя каких Святых или Библейских Событий был Освящён храм } \\
\text { и его приделы в различные эпохи? }\end{array}$ & 12 & 0 \\
\hline 2. & На территории какого стана ${ }^{1}$, располагается село? & 6 & 3 \\
\hline 3. & $\begin{array}{l}\text { Владельцем села является частное лицо или духовное, дворцовое, } \\
\text { экономическое ведомство и т.п.? В случае владельца — частного } \\
\text { лица, каковы его имя, фамилия или прозвище? } \\
\text { Какие из наиболее видных персон когда-либо владели селом? }\end{array}$ & 5 & 0 \\
\hline 4. & $\begin{array}{l}\text { Вблизи каких (типы и названия) объектов местности (например: рек, } \\
\text { озёр, болот и т.п.) располагается село? }\end{array}$ & 3 & 1 \\
\hline 5. & $\begin{array}{l}\text { На территории какого природного объекта располагается или перво- } \\
\text { начально было образовано село (урочища, луга и т.п.)? }\end{array}$ & 1 & 0 \\
\hline 6. & Какие поселения располагаются вблизи села? & 0 & 3 \\
\hline 7. & Какие поселения приписаны к селу (деревни «при селе» и т.п.)? & 0 & 0 \\
\hline 8. & $\begin{array}{l}\text { Какие поселения входят в приход расположенного на территории } \\
\text { села храма? }\end{array}$ & 0 & 0 \\
\hline 9. & $\begin{array}{l}\text { Каковы количественные характеристики села: количество дворов, } \\
\text { число проживающих в нём крестьянских душ и т.п.? }\end{array}$ & 0 & 0 \\
\hline
\end{tabular}

${ }^{1}$ Стан - одна из единиц административно-территориального деления, использовавшаяся в России 


\section{ВЫВОДЫ}

Выполненные для совокупности сёл Рузского уезда Московской губернии в XVI-XIX вв. исследования позволили систематизировать критерии идентификации сёл, а также предложить и апробировать соответствующую методику. Экспериментальное применение предложенной методики показало её результативность и эффективность.

\section{СПИСОК ЛИТЕРАТУРЫ}

1. Бобринский А.А. Дворянские роды, внесенные в Общий гербовник Российской Империи. Ч. 1. СПб.: Тип. М.М. Стасюлевича, 1890.800 с.

2. Кистерёв С.Н., Тимошина Л.А. Рузский уезд по писцовой книге 1567-1569 гг. Материалы для истории Звенигородского края. Вып. 4. М.: Памятники исторической мысли, 1997. 300 c.

3. Кондрашина В.А., Лукичёв М.П., Тихонюк И.А. Приправочный список с писцовых книг Звенигородского уезда 1558-1560 гг. Материалы для истории Звенигородского края. Вып. 1. М.: Памятники исторической мысли, 1992. 156 с.

4. Красовский А.П. О названиях поселений прихода Казанской церкви села Брынкова, или как я определил название одного сельца, и что из этого получилось. Землеустройство, кадастр и мониторинг земель, 2018. № 5. С 73-77.

5. Красовский А.П., Тетерюков А.И. Отражение истории поиска уникальных названий для двух сёл Горбовых в документах и на картах XVII-XX вв. Землеустройство, кадастр и мониторинг земель, 2019. № 8. С. 66-73.

6. Красовский А.П. Никольское? А какое из них? Или о названиях двух сёл Никольских Рузского уезда Московской губернии. Землеустройство, кадастр и мониторинг земель, 2020. № 3. C. 68-76.

7. Кусов В.С. Земли Московской губернии в XVIII веке. Карты уездов. Описание землевладений. Т. 3. Карты 14 л. М.: Издательский дом «Московия», 2004.

8. Кусов В.С. Станы и волости на землях Московской губернии. Карты по данным генерального межевания 1766-1770 гг. Памятники отечественной картографии и земли Подмосковья. М.: Участникам и гостям XXIII Международной картографической конференции, 4-10 августа 2007 г.

9. Фролов А.А., Голубинский А.А., Кутаков С.С. Веб-ГИС «Чертежи Русского государства XVI-XVII вв. (http://rgada.info/geos2) Историческая информатика, 2017. № 1. C. 75-84. DOI: 10.7256/2306-0891.2017.1.22025. Электронный pecypc: http://e-notabene.ru/istinf/article_ 22025.html (дата обращения 01.11.2019).

10. Фролов А.А., Голубинский А.А. Новые чертежи XVII в., выявленные в фондах РГАДА. Российская история. М.: РАН, 2019. № 2. С. 71-77.

11. Холмогоров В.И., Холмогоров Г.И. Исторические материалы для составления церковных летописей Московской епархии. Вып. 1. А: Рузская десятина. М.: Тип. Л.Ф. Снегирёва, $1881.288 \mathrm{c}$.

12. Холмогоров В.И., Холмогоров Г.И. Исторические материалы для составления церковных летописей Московской епархии. Вып. 2. Б. Звенигородская десятина. М.: Тип. Л.Ф. Снегиpёва, 1881. 133 с. Электронный ресурс: http://elib.shpl.ru/ru/nodes/16-vyp-2-bzvenigorodskaya-desyatina-1881 (дата обращения 12.09.2018).

13. Холмогоров В.И., Холмогоров Г.И. Исторические материалы для составления церковных летописей Московской епархии. Вып. 3. В: Загородская десятина Московского уезда. М.: Тип. Л.Ф. Снегирёва, 1881. 387 с.

14. Холмогоров В.И., Холмогоров Г.И. Исторические материалы для составления церковных летописей Московской епархии. Вып. 10: Можайская десятина Московского уезда. М.: Тип. Л.Ф. Снегирёва, 1901. 288 с. 
15. Холмогоров В.И., Холмогоров Г.И. Исторические материалы для составления церковных летописей Московской епархии. Вып. 13: Верейская, Дмитровская и Троицких вотчин десятины (Московского уезда). М.: Тип. Л.Ф. Снегирёва, 1913. 380 с.

\section{REFERENCES}

1. Bobrinsky A.A. Noble families included in The General coat of arms of the all Russian Empire. Part 1. St. Petersburg: Typ. by M.M. Stasyulevich, 1890. 800 p. (in Russian).

2. Frolov A.A., Golubinsky A.A. New drawings of the XVII century, identified in the funds of RGADA Russian history, Moscow: RAS, 2019. No 2. P. 71-77 (in Russian).

3. Frolov A.A., Golubinsky A.A., Kutakov S.S. Web-GIS «Drawings of the Russian state XVI-XVII centuries» (http://rgada.info/geos2). Historical Informatics, 2017. No 1. P. 75-84. DOI: 10.7256/2306-0891.2017.1.22025. Web resource: http://rgada.info/geos2 (accessed 01.11.2019) (in Russian).

4. Kholmogorov V.I., Kholmogorov G.I. Historical materials for compiling Church Chronicles of the Moscow diocese. V. 1 A: Ruzskaya tithe. Moscow: Tip. by L.F. Snegirev, 1881. 288 p. (in Russian).

5. Kholmogorov V.I., Kholmogorov G.I. Historical materials for the compilation of Church Chronicles of the Moscow diocese. Zvenigorodskaya tithe of the Moscow district. Moscow: Typ. by L.F. Snegirev, 1881. V. 2. 133 p. (in Russian).

6. Kholmogorov V.I., Kholmogorov G.I. Historical materials for the compilation of Church Chronicles of the Moscow diocese. V. 3. C. Zagorodskaya tithe of the Moscow district. Moscow: Typ. by L.F. Snegirev, 1881. 387 p. (in Russian).

7. Kholmogorov V.I., Kholmogorov G.I. Historical materials for the compilation of Church Chronicles of the Moscow diocese. V. 10. Mozhaiskaya tithe of the Moscow district. Moscow: Typ. by L.F. Snegirev, 1901. 288 p. (in Russian).

8. Kholmogorov V.I., Kholmogorov G.I. Historical materials for the compilation of Church Chronicles of the Moscow diocese. V. 13. Vereyskaya, Dmitrovskaya and Troitsky fiefdoms of tithe (Moscow district). Moscow: Typ. by L.F. Snegirev, 1913. 380 p. (in Russian).

9. Kisterev S.N., Timoshina L.A. Ruzsky district according to the scribe's book of 1567-1569. Materials for the history of Zvenigorod region. V. 4. Moscow: Monuments of historical thought, 1997. 300 p. (in Russian).

10. Kondrashina V.A., Lukichev M.P., Tikhonyuk I.A. Seasoning list from the scribal books of Zvenigorod district 1558-1560. Materials for the history of Zvenigorod region. V. 1. Moscow: Monuments of historical thought, 1992. 156 p. (in Russian).

11. Krassowski A.P. On the settlement names of prikhod Church Kazanskoy of rural Brinkovo, or How I determined the name of one rural, and what came of it. Land use planning, cadastre and land monitoring, 2018. No 5. P. 73-77 (in Russian).

12. Krassowski A.P., Teterukov A.I. Reflection of the history of the search for unique names for two rural Gorbovykh in documents and maps of the XVII-XX centuries. Land use planning, cadastre and land monitoring, 2019. No 8. P. 66-73 (in Russian).

13. Krassowski A.P. Nikol'skoye? And what of them? Or about the names of two rural Nikol'sky Ruzsky district of Moscow province. Land use planning, cadastre and monitoring of land, 2020. No 3. P. 68-76 (in Russian).

14. Kusov V.S. Lands of the Moscow province in the XVIII century. Maps of the counties. Description of land holdings. V. Maps 14 sh. Moscow: Publishing House "Moskovia", 2004 (in Russian).

15. Kusov V.S. Camps and townships on the lands of the Moscow province. Maps according to the General survey of 1766-1770. Monuments of national cartography and the land of the Moscow region. Moscow: To participants and guests of the XXIII International cartographic conference, 4-10 august 2007 (in Russian). 